\title{
COPYRIGHT POLICYMAKING AS PROCEDURAL DEMOCRATIC PROCESS: A DISCOURSE- THEORETIC PERSPECTIVE ON ACTA, SOPA, AND PIPA
}

\begin{abstract}
ANNEMARIE BRIDY*
Read in discourse-theoretic terms, the principle of popular sovereignty states that all political power derives from the communicative power of citizens. The exercise of public authority is oriented and legitimated by the laws citizens give themselves in a discursively structured opinionand will-formation. ${ }^{1}$

- Jürgen Habermas
\end{abstract}

In Bring in the Nerds: Secrecy, National Security, and the Creation of Intellectual Property Law, David Levine juxtaposes two starkly different copyright policymaking processes: the closed international process that produced the Anti-Counterfeiting Trade Agreement (ACTA) and the relatively open domestic process that led quite dramatically to the scuttling of the Stop Online Piracy Act (SOPA) and the PROTECT IP Act (PIPA). ${ }^{2}$ He reads the two processes against each other as a prelude to recommending Freedom of Information Act (FOIA) reform. ${ }^{3}$ The amendment to FOIA that Professor Levine proposes would open the international IP policymaking process to greater public scrutiny by creating a qualified public right to "foreign

\footnotetext{
- Permission is hereby granted for noncommercial reproduction of this Article in whole or in part for education or research purposes, including the making of multiple copies for classroom use, subject only to the condition that the name of the author, a complete citation, and this copyright notice and grant of permission be included in all copies.

* Fellow and Visiting Associate Research Scholar, Princeton University Center for Information Technology Policy (CITP); Associate Professor of Law, University of Idaho College of Law. This Article was prepared for and presented at the Cardozo Arts \& Entertainment Law Journal Symposium on "Piracy and the Politics of Policing: Legislating and Enforcing Copyright Law" at Benjamin N. Cardozo School of Law, Yeshiva University. The author would like to thank the student organizers of the symposium and her fellow panelists, Mary LaFrance, David Levine, and Eva Subotnik, for a valuable opportunity to engage important, timely questions about public participation in international and domestic copyright policymaking. (C) 2012 Annemarie Bridy.

1 JÜRgEN HABERMAS, BETWEen FACTS AND NORMS: CONTRIBUTIONS TO A DisCOURSE THEORY OF LAW AND DEMOCRACY 170 (William Rehg trans., Polity Press 1998).

2 David Levine, Bring in the Nerds: Secrecy, National Security, and the Creation of Intellectual Property Law, 30 CARDOZO ARTS \& ENT. L. J. 105 (2012). Stop Online Piracy Act, H.R. 3261, 112th. Cong. (2011) (SOPA), was the House version of "rogue site" legislation; PROTECT IP Act, S. 968, 112th Cong. (2011) (PIPA), was the Senate version.

${ }^{3}$ Levine, supra note 2, at 114.
} 
relations" national security information, which was systematically withheld from the public during ACTA negotiations. ${ }^{4}$ This Article responds to Professor Levine's by drawing on Jürgen Habermas' discourse theory of procedural democracy to examine the policymaking dynamics of ACTA and SOPA/PIPA and to assess the democracyenhancing potential of Professor Levine's proposal for FOIA reform.

Both ACTA and SOPA/PIPA contained copyright enforcement measures touted by their proponents as necessary to prevent online piracy and to protect U.S. jobs in the film, television, and music industries. ${ }^{5}$ Both frameworks contemplated an increased role for online intermediaries, with SOPA/PIPA's most controversial provisions requiring operators of the Internet's addressing system, the Domain Name System (DNS), to block access to "foreign infringing sites" that traffic illegally in copyrighted content. ${ }^{6}$ ACTA's provisions were finalized in 2010, and the United States signed the agreement in 2011.7 It will enter into force when it is formally ratified by six of the eight negotiating parties. ${ }^{8}$ Neither SOPA nor PIPA will become law as they were initially drafted, ${ }^{9}$ although they may spawn less technically problematic, more publicly palatable alternatives. ${ }^{10}$

In Between Facts and Norms: Contributions to a Discourse Theory

\footnotetext{
4 Id.

5 See Anti-Counterfeiting Trade Agreement (ACTA), OfFICE OF THE U.S. TRADE REPRESENTATIVE, EXEC. OfFICE OF THE PRESIDENT, http://www.ustr.gov/acta (lasted visited Apr. 16, 2012) (stating that ACTA "will help to support American jobs in innovative and creative industries against intellectual property theft"); Hearing on: H.R. 3261, the "Stop Online Piracy Act," U.S. HOUSE OF REPRESENTATIVES COMM. ON THE JUDICIARY, available at http://judiciary.house.gov/hearings/hear_11162011.html (last visited Apr. 16, 2012) (stating that SOPA "protect[s] American jobs" by giving the Attorney General power to block access to "foreign websites that steal and sell American innovations and products").

${ }^{6}$ See Stop Online Piracy Act, H.R. 3261, 112th Cong. § 102(c)(2)(A)(i) (2011) (“A service provider shall take technically feasible and reasonable measures designed to prevent . . . the domain name of the foreign infringing site (or portion thereof) from resolving to that domain name's Internet Protocol address.”); PROTECT IP Act, S. 968, 112th Cong. § 3(d)(2)(A)(i) (2011) ("An operator of a nonauthoritative domain name system server shall take the least burdensome technically feasible and reasonable measures designed to prevent the domain name described in the order from resolving to that domain name's Internet protocol address. ...").

ACTA does not contain provisions that require DNS blocking. See Annemarie Bridy, ACTA and the Specter of Graduated Response, 26 AM. U. INT'L L. REV. 559 (2011) (discussing the evolution of the provisions of ACTA concerning copyright enforcement in the digital environment).

7 Anti-Counterfeiting Trade Agreement (ACTA), supra note 5.

8 Id.

9 See Julianne Pepitone, SOPA and PIPA Postponed Indefinitely after Protests, CNN MONEY $\begin{array}{llll}\text { (Jan. } 20, & 2012, & 7: 54 & \text { PM), }\end{array}$ http://money.cnn.com/2012/01/20/technology/SOPA_PIPA_postponed/index.htm. 10 The Online Protection and Enforcement of Digital Trade Act, H.R. 3782, 112th Cong. (2012) (OPEN Act), for example, was introduced as a fairer and more infrastructure-friendly countermeasure to SOPA/PIPA. See also Christina DesMarais, SOPA, PIPA Stalled: Meet the OPEN Act, PCWORLD (Jan. 21, 2012, $1: 15$ PM), https://www.pcworld.com/article/248525/sopa_pipa_stalled_meet_the_open_act.html ("OPEN [gives] oversight to the International Trade Commission (ITC) instead of the Justice Department, focuses on foreign-based websites, includes an appeals process, and [applies] only to websites that 'willfully' promote copyright violation.").
} 
of Law and Democracy, Habermas argues that legitimate policymaking requires specific forms of communication between the law's makers (i.e., legislative decision makers) and its addressees (i.e., citizens). ${ }^{11} \mathrm{He}$ proposes a model of policymaking as two-way communicative action that stands in contrast to a model in which lawmakers operate in a primarily closed, self-referential system that "bypasses the communicative power of the public of citizens" and operates according to its own internal code and logic. ${ }^{12}$ His model stands in contrast, too, to a model of open government à la FOIA, which relies for its openness on ex post public disclosure of government information. ${ }^{13}$ In FOIA's information economy, citizens are positioned as supplicants whose access to the legislative process lies in the information they can periodically extract from it through formal requests.

Implicitly rejecting the idea of democracy through disclosure, Habermas calls for dialogue in the process of policy formation - a twoway discourse between lawmakers and citizens that positions citizens as interlocutors rather than supplicants. ${ }^{14}$ Such dialogue would be encouraged in international copyright policymaking by Professor's Levine's proposal to amend FOIA to create a qualified public right to U.S. "foreign relations" national security information, but it would not necessarily follow from such an amendment. This is structurally true because FOIA's communicative model locates government openness in the flow of information from government, not the flow of information to it. Given the unidirectionality of that information flow, FOIA reform can only go so far to help create the necessary conditions for procedurally democratic policymaking. In other words, FOIA can deliver government information, but it cannot deliver open government. Although Professor Levine's analysis in Bring in the Nerds is tacitly discourse theoretic in its recognition of the need for bidirectional information flows in policymaking, his proposal to amend FOIA operates on only one side the communicative equation.

11 HABERMAS, supra note 11 , at 170 ("Read in discourse-theoretic terms, the principle of popular sovereignty states that all political power derives from the communicative power of citizens. The exercise of public authority is oriented and legitimated by the laws citizens give themselves in a discursively structured opinion- and will-formation.").

$12 \mathrm{Id}$. at 352. Habermas is critical of a systems-theoretic model in which politics and lawmaking function as "autonomous, recursively closed circuit[s] of communication furnished with [their] own code." Id. at 341.

13 Under FOIA, any member of the public may request documents from a government agency, and the agency to which the request was directed must identify responsive documents in its possession and disclose them to the requester, unless one or more of nine enumerated statutory exemptions apply. The requester may challenge any asserted exemption in court. See generally Patricia M. Wald, The Freedom of Information Act: A Short Case Study in the Perils and Paybacks of Legislating Democratic Values, 33 EMORY L.J. 649 (1984) (describing the mechanics of FOIA and its underlying model of open government).

14 HABERMAS, supra note 1, at 171 ("Parliamentary opinion- and will-formation must remain anchored in the informal streams of communication emerging from public spheres that are open to all political parties, associations, and citizens.”). 
Professor Levine's title invokes the words of Rep. Jason Chaffetz (R-Utah), a member of the House Judiciary Committee and its Subcommittee on Intellectual Property, Competition, and the Internet. During the Judiciary Committee's hearing on SOPA, Rep. Chaffetz worried aloud to his colleagues that they were preparing to make Internet policy without any actual understanding of the likely technical consequences:

I understand that [online piracy] is a problem, but I worry that this is the wrong remedy. I was trying to think of a way to try to describe my concerns with this bill, but basically we are going to do surgery on the Internet, and we haven't had a doctor in the room tell us how we['re] going to change these organs. We are basically going to reconfigure the Internet and how it is going to work without bringing in the nerds, without bringing in the doctors. ${ }^{15}$

The insight is as sensible as the metaphor is awkward: legislators should know whereof they legislate, which requires reliance on professional expertise from beyond the Beltway.

Rep. Chaffetz's reference to "the nerds" was revisited during the hearing by his colleague, SOPA supporter Rep. Mel Watt (R-N.C.), also a member of the Subcommittee on Intellectual Property, Competition, and the Internet. Rep. Watt opened his remarks by describing himself as an "old-fashioned guy who still hasn't figured out how, or even whether, [he wants] to use all the fancy technological advances that are out there."16 Later in the hearing, he sidestepped technical concerns about SOPA by explaining that he is "not a nerd" and "doesn't understand a lot of the technological stuff." 17 Unlike Rep. Chaffetz, who was unprepared to support a piece of legislation he didn't understand, Rep. Watt was both unfazed and undeterred by his own ignorance. For him, understanding "the technological stuff" was immaterial to his support for the legislation: piracy is a problem; here was a solution. Putting aside his appointment to the Subcommittee on Intellectual Property, Competition, and the Internet, why did he need to know anything about how the Internet works?

Statements like Rep. Watt's reveal a troubling nonchalance on the part of policymakers when it comes to understanding the objects of their regulation. They also highlight the need for policymakers to educate themselves by opening the legislative process to the voices - and the expertise - of people outside government and beyond the class of

15 Stop Online Piracy Act: Markup Hearing on H.R. 3261 Before the H. Comm. on the Judiciary, 112th Cong. 88 (2012) (statement of Rep. Chaffetz).

16 Id. at 74 (statement of Rep. Watt).

17 Id. at 180 . 
professional "educators" who have their offices on K Street. What policymakers need, as Rep. Chaffetz recognized, are experts from civil society who do understand the objects of proposed regulation. What they needed in the case of SOPA/PIPA were the nerds.

To develop the argument that policymaking processes open to expert input ultimately yield better policy —or at least help prevent bad policy-Professor Levine juxtaposes the "closed code environment" in which ACTA was negotiated with the "comparatively transparent and accountable processes" associated with the policy debates over SOPA/PIPA. ${ }^{18}$ As Professor Levine explains, the shroud of secrecy around the negotiation of ACTA was sustainable despite regular requests for documents under FOIA because the government appealed - at best incongruously and at worst cynically - to the statute's national security exemption to justify its refusal to disclose information about the U.S. negotiating position. ${ }^{19}$ The FOIA denials came even as the United States Trade Representative, Ron Kirk, continued to assert that the administration was maintaining an "open-door policy toward all stakeholders" in the ACTA process. ${ }^{20}$

Information from inside the ACTA process, including deliberative drafts, did ultimately reach the public via a series of unauthorized leaks. ${ }^{21}$ Such leaks came, however, in plain breach of the nondisclosure agreement (NDA) that ACTA negotiators were required to sign before entering negotiations. Under the NDA, the circulation of information and documents was limited to government officials and consulting parties outside government with a "need to review or be advised." 22 The highly restrictive terms of the agreement cast doubt on Ambassador Kirk's public claims concerning his office's commitment to transparency. In reality, the door to the ACTA process was closed to the public from the outset.

Although criticism of the ACTA process focused mostly on the lack of public access to negotiating drafts, there were serious problems,

18 Levine, supra note 2, at 132-40.

$19 \mathrm{Id}$. at $127-30$.

20 Press Release, Office of the U.S. Trade Representative, Press Release, Ambassador Ron Kirk Announces Plan to Move Forward With the Negotiation of the Anti-Counterfeiting Trade Agreement (ACTA) (June 2009), available at http://www.ustr.gov/about-us/press-office/pressreleases/2009/june/ambassador-ron-kirk-announces-plan-move-forward-negot (internal quotation marks omitted).

21 See, e.g., Paul Meller, Leaked ACTA Draft Treaty Reveals Plans for Net Clampdown, $\begin{array}{lllll}\text { PCWORLD (Feb. } & 19, & 2010, & 1: 40 & \text { PM), }\end{array}$ https://www.pcworld.com/article/189812/leaked_acta_draft_treaty_reveals_plans_for_net_clamp down.html (reporting on a series of leaks from the ACTA negotiations); David Kravets, ACTA Draft: No Internet for Copyright Scofflaws, WIRED.COM (Mar. 24, 2010 4:30 PM), http://www.wired.com/threatlevel/2010/03/terminate-copyright-scofflaws/ (reporting on the leak of a 56-page draft of ACTA on Jan. 18, 2010).

22 Declaration of Assistant USTR Stanford McCoy, Elec. Frontier Found. v. U.S. Trade Rep., Civil Action No. 08-1599 (D.D.C. 2008), available at https://www.eff.org/files/filenode/EFF_PK_v_USTR/McCoy.pdf (quoting the nondisclosure agreement). 
too, with ACTA's knowledge and information inputs. Even when the USTR, acting in response to public criticism, temporarily widened its circle of advisors to include representatives from the Center for Democracy and Technology and Public Knowledge, those advisors were required, like the negotiators themselves, to sign the NDA. Representatives of public interest groups that were not chosen by USTR questioned the wisdom and fairness of allowing the agency to seemingly arbitrarily pick and choose its interlocutors from the public interest community, which, in the world of intellectual property and technology policy, is quite internally diverse. ${ }^{23}$ Under the guise of opening the process to a range of voices from civil society, the USTR anointed representatives from two public interest groups and then made them promise, in exchange for access, to withhold from the public everything they saw and heard. ${ }^{24}$ Through this Faustian bargain, ACTA's critics were strategically interpellated ${ }^{25}$ as accomplices in what ACTA critic Margot Kaminski has called "transparency theater."26 The solution was a public relations gesture designed to create the appearance of increased openness, not a structural solution designed to actually increase openness.

In sharp contrast to deliberations over ACTA, congressional deliberations over SOPA/PIPA were marked by a much more open flow of information between policymakers and the public. This was due in large part to the free availability of the primary documents and an interest in their contents that propagated virally across the Internet and social media. ${ }^{27}$ Online opposition to the two bills coalesced quickly as

23 See James Love, White House Shares the ACTA Internet Text with 42 Washington Insiders, under Non Disclosure Agreements, KNOWLEDGE ECOLOGY INT'L (Oct. 13, 2009, 4:10 PM), http://www.keionline.org/node/660 (quoting Robert Weissman, President of Public Citizen, who asserted that "ad hoc processes to choose a few public interest representatives to comment on material, to counterbalance the broad sharing of the material with a wide swath of self-interested corporations is a deeply flawed process[,]" because "[p]ublic interest groups have different interests, orientations, conflicts and areas of expertise").

24 In a press release, the USTR announced that it had broadened its consultations to include a diverse range of views including not only the cleared advisors who give input to USTR on a regular basis on intellectual property matters, but also to interested domestic stakeholders representing a broad range of views and expertise on internet and digital issues, including representatives from non-governmental organizations (NGOs). See Love, supra note 2323 (quoting a press release issued by Carol Guthrie, Assistant USTR for Public and Media Affairs).

25 The term was coined by Louis Althusser to describe the process by which an individual becomes assimilated to the organizational and power dynamics of particular social institutions like the family, organized religion, and the educational system. LOUIS ALTHUSSER, LENIN AND PHILOSOPHY AND OTHER ESSAYS 173-75 (Ben Brewster trans., 1971). The individual is "hailed" or addressed by the institution in question and asked to respond to the address in terms that the institution expects or recognizes as appropriate. Id. Interpellation occurs when the individual responds in the expected or prescribed way. $I d$. Through interpellation, the individual becomes ostensibly voluntarily subject to the hailing organization's beliefs, assumptions, and dictates. Id.

26 Timothy B. Lee, Obama Admin: War Is Peace, IP Negotiations Are Transparent, ARS TECHNICA (Mar. 8, 2012, 2:00 PM), http://arstechnica.com/tech-policy/news/2012/03/obamaadmin-war-is-peace-tpp-negotiations-are-transparent.ars.

27 The official text of both bills was available, for example, via the THOMAS portal at the 
word spread that SOPA/PIPA contained provisions requiring the blacklisting of websites. In an open letter to Congress, Google cofounder Sergey Brin and other prominent Internet entrepreneurs asserted that the legislation would give the U.S. government "power to censor the web using techniques similar to those used by China . . . and Iran." 28 Contributing to and marshaling web-roots resistance, the operators of Wikipedia made the unprecedented decision to "go dark" in protest for one day-January 18, 2012. ${ }^{29}$ In addition to Wikipedia, more than 100,000 Internet companies, including Google, Mozilla, Reddit, and I Can Has Cheezburger (of LOLcats fame), joined the one-day protest. ${ }^{30}$ Their forms of protest varied, but their message to their users and fans was unitary: "Petition your elected representatives to oppose these bills." And petition their representatives people did-in droves. Google reported that 4.5 million people in one day signed its petition opposing SOPA and PIPA. ${ }^{31}$ Unlike official support for ACTA, which never wavered in the face of persistent critiques from the public and civil society groups, congressional support for SOPA/PIPA quickly evaporated in the face of mass networked resistance. ${ }^{32}$ Even the White

\begin{tabular}{l}
\hline Library of Congress. THOMAS, LIBRARY OF CONGRESS, \\
http://thomas.loc.gov/home/thomas.php. \\
28 Open Letter from Mark Andreessen et al. to Washington (Dec. 14, 2012), available at \\
https://dq99alanzv66m.cloudfront.net/sopa/img/12-14-letter.pdf (last visited Apr. 17, 2012). See \\
also Cecilia Kang, Google's Brin Calls SOPA Censorship Akin To China, Iran, WASH. POST \\
(Dec. 15, 2011, 1:15 PM), http://www.washingtonpost.com/blogs/post-tech/post/googles-brin- \\
calls-sopa-censorship-akin-to-china-iran/2011/12/15/gIQAlV2HwO_blog.html (reporting on the \\
contents of an open letter to Congress signed by Google co-founder Sergey Brin and other
\end{tabular}
Internet entrepreneurs).

29 See SOPA Protests Planned by Google, Wikipedia and Others on Jan. 18, WASH. Post (Jan. 17, 2012), http://www.washingtonpost.com/business/economy/sopa-protests-planned-by-googlewikipedia-and-others-on-jan-18/2012/01/17/gIQALKBL6P_story.html.

30 See, e.g., David A. Fahrenthold, SOPA Protests Shut Down Web Sites, Wash. PosT http://www.washingtonpost.com/politics/sopa-protests-to-shut-down-web-

sites/2012/01/17/gIQA4WY16P_story.html; End Piracy, Not Liberty, GoogLe, https://www.google.com/takeaction/ (last visited Apr. 2, 2012) (reporting that over 115,000 Web sites participated in the January 18 blackout/strike).

31 See Deborah Netburn, Google Says 4.5 Million People Signed Anti-SOPA Petition Today, L.A. TIMES (Jan. 18, 2012, 4:00 PM), http://latimesblogs.latimes.com/technology/2012/01/google-antisopa-petition.html. An anti-SOPA petition on the White House's "We the People" web site garnered 51,689 signatures. See We Petition the Obama Administration to: Veto the SOPA Bill, We the PEOPLE: YOuR VOICE IN OUR GOVERnMent, THE White House, https://wwws.whitehouse.gov/petitions\#!/petition/veto-sopa-bill-and-any-other-future-billsthreaten-diminish-free-flow-information/g3W1BscR. An earlier "We the People" petition opposing the immediate precursor of SOPA, the E-PARASITES Act, was signed by 52,096 people. See Megan Slack, By the Numbers:103,785, THE White House Blog (Jan. 18, 2012, 4:15 PM), http://www.whitehouse.gov/blog/2012/01/18/numbers-103785. The two White House petitions prompted a supportive response from the Obama administration. See Macon Phillips, Obama Administration Responds to We the People Petitions on SOPA and Online Piracy, THE White HOUSE BLOG (Jan. 14, 2012, 8:09 AM), http://www.whitehouse.gov/blog/2012/01/14/obama-administration-responds-we-peoplepetitions-sopa-and-online-piracy ("While we believe that online piracy by foreign websites is a serious problem that requires a serious legislative response, we will not support legislation that reduces freedom of expression, increases cybersecurity risk, or undermines the dynamic, innovative global Internet.").

32 See Jennifer Martinez \& Tony Romm, SOPA Blackout Leads Co-Sponsors to Defect, POLITICO 
House came out against them. ${ }^{33}$

The policymaking processes that brought ACTA to fruition and SOPA/PIPA to heel are very different deliberative models driven by divergent discourse dynamics. Analyzing the two processes in terms of procedural democracy leads to the conclusion that the process associated with SOPA/PIPA has the greater normative claim to democratic legitimacy. For Habermas, lawmaking processes meet the conditions for democratic legitimacy "only if they remain porous, sensitive, and receptive to the suggestions, issues and contributions, information and arguments that flow from a discursively structured public sphere, that is, one that is pluralistic, close to the grass roots, and relatively undisturbed by the effects of power." 34 The hermetic environment in which ACTA developed was anything but porous and receptive to input from the grass roots. Nor was the process pluralistic, as Professor Levine points out, because the only inputs invited from outside government came from "cleared advisors" who were predominantly representatives of the industries seeking greater protection for their intellectual property through the agreement. ${ }^{35}$ The inclusion of civil society groups in the process was more symbolic than real, and it occurred only after criticism of the closed nature of the negotiations became too persistent and too publicly visible for the USTR to continue to ignore.

Policymakers operating within the model of procedural democracy that Habermas describes are obliged not only to disclose information, for example by releasing documents in response to open records requests, but also to solicit it: "[T]he production of legitimate law through deliberative politics represents a problem-solving procedure that needs and assimilates knowledge in order to program the regulation of conflicts and the pursuit of collective goals." 36 Lawmaking as institutionalized problem-solving relies on information and opinion inputs from the public as well as outputs to it, and the conduits through which those inputs and outputs flow must be structural, multiple, and open. Policymaking in the discourse-theoretic sense is not an autistic endeavor, although that is essentially what it became in the process that produced ACTA. ${ }^{37}$ Nor is it a process whose requirement for communicative openness can be satisfied by a FOIA document dump. On this point, Professor Levine is right when he argues that it would be

(Jan. 18, 2012, 1:30 PM), http://www.politico.com/news/stories/0112/71589.html (reporting that PIPA co-sponsor Sen. Marco Rubio (R-Fla.) and SOPA co-sponsor Rep. Ben Quayle (R-Ariz.) withdrew their support for the bills).

33 See Phillips, supra note 31.

${ }^{34}$ HABERMAS, supra note 1 , at 182.

35 Levine, supra note 2, at 134-35.

36 HABERMAS, supra note 11 , at 318.

37 Id. at 335 (describing as "autistic" a systems view of politics that "self-referentially closes itself off from its environment"). 
a mistake to think that the problems of democratic legitimacy that came to the fore in ACTA can be magically fixed by more disclosure (i.e., increased output). ${ }^{38}$

More outputs from government are not democracy-enhancing by themselves. They can lead to increased transparency, which is the remedy that critics of ACTA consistently demand; but there is an important distinction to be made between the ability to see what is happening in government and the ability to influence it. ${ }^{39}$ Transparency, in other words, is a precondition and not a synonym for openness. In the same way that FOIA's model of open government positions citizens as information supplicants, a transparency-based model of open government positions citizens as policymaking spectators. In neither model do citizens have a structural and proactive voice in policy formation.

When it comes to inputs for digital copyright policymaking, the voices to which policymakers must be attuned include those of technical experts and civil society groups in addition to those of aggrieved copyright owners, who tend to speak more often and more loudly than other constituents. At the House Judiciary Committee hearing on SOPA, no technical expert testified, though such testimony would certainly have gone a long way to remedy the knowledge deficit from which Rep. Watt admittedly suffered. Representatives of Pfizer, the pharmaceutical company, and the Motion Picture Association of America (MPAA) testified on behalf of intellectual property owners. ${ }^{40}$ Representatives of Google and MasterCard testified on behalf of online intermediaries whose business practices the bill sought to regulate. ${ }^{41} \mathrm{~A}$ representative of the AFL-CIO testified on behalf of the copyright industries' rank-and-file union members. ${ }^{42}$ (Remember that the bills were put forward as job-saving.) Nobody, however, testified on behalf of Internet engineers or Internet users.

The exclusion of disinterested technical experts from the SOPA hearing is symptomatic of a myopic but increasingly entrenched view of intellectual property policymaking as a process of bargaining between different sets of corporate "stakeholders" with competing business interests-e.g., copyright owners and Internet intermediaries. ${ }^{43}$ Within

38 See Levine, supra note 2, at 141-46.

39 Professor Levine speculates, recognizing that one can only speculate, that the substance of ACTA would be different if there had been greater transparency in the negotiating process. David Levine, Transparency Soup: The ACTA Negotiating Process And "Black Box" Lawmaking, 26 AM. U. INT'L L. REV. 811, 814 (2011).

40 See Hearing on: H.R. 3261, the "Stop Online Piracy Act," U.S. House OF REPRESENTATIVES COMM. ON THE JUDICIARY, http://judiciary.house.gov/hearings/hear_11162011.html (last visited Apr. 16, 2012) (listing the witnesses invited to testify at the hearing in the right-hand sidebar).

${ }^{41} I d$.

$42 \mathrm{Id}$.

43 See, e.g., Jessica Litman, Digital Copyright 22-34 (2006) (arguing the Congress has traditionally ceded substantive copyright policymaking to lawyers representing affected 
the frame of procedural democratic process, this understanding is incomplete insofar as it fails to account for the need of policymakers to understand the objects of their regulation as well as the competing interests to be balanced through it. Good policy, from a procedural democratic point of view, flows not from legislatively brokered deals but from "the institutionalization of interlinked forms of communication that, ideally speaking, ensure that all relevant questions, issues, and contributions are brought up and processed in discourses and negotiations on the basis of the best available information and arguments." 44 Reaching political compromise is necessary, in other words, but democratically legitimate compromises cannot be reached in an epistemic vacuum, where corporate interests are the primary drivers of policy formation, and other concerns, such as technical ones, are viewed as irrelevant or incidental. ${ }^{45}$

Official exclusion, thankfully, did not stop Internet engineers from "talking back" to the legislature-from engaging, as Habermas might say, in communicative action designed to influence political willformation. ${ }^{46}$ Eighty-three computer and network engineers-a group described as a "who's-who of the proud geeks who built the modern Internet" 47 - wrote an open letter to Congress opposing the bills as "censorship of Internet infrastructure" and warning that compliance with their provisions would have "capricious technical consequences" for the global DNS and its security and stability. 48 Only the nerds, really, were in a position to deliver the "best available information and arguments" about the technical implications and consequences of DNS blocking. And although they were outside the Beltway, and lacked access to the circuits of official power, the policymaking process was

industries). With respect to online copyright enforcement in the peer-to-peer file sharing context, the Obama administration has encouraged lawyers for copyright owners and lawyers for ISPs to reach private cooperative agreements entirely outside the public policymaking process. Annemarie Bridy, Graduated Response and the Turn to Private Ordering in Online Copyright Enforcement, 89 OR. L. REV. 81, 132 (2010).

44 HABERMAS, supra note 1, at 170.

45 The Internet intermediaries that opposed SOPA/PIPA did make technology-based arguments in addition to business arguments opposing the bills' DNS provisions. See, e.g., Letter from AOL Inc. et al. to Members of the House Judiciary Comm. (Nov. 15, 2011), available at http://www.protectinnovation.com/downloads/letter.pdf (last visited Apr. 17, 2012) (raising cybersecurity concerns). Proponents of the bills dismissed such arguments as self-serving. See, e.g., Scott Cleland, The Real Reasons Google Killed SOPA/PIPA, FORBES (Jan. 24, 2012, 10:53 AM), http://www.forbes.com/sites/scottcleland/2012/01/24/the-real-reasons-google-killedsopapipa (arguing that "Google and others that protested against SOPA/PIPA believe that a "free and open internet' means that they do not have to pay for Internet content").

$46 \mathrm{Cf}$. HABERMAS, supra note 1 , at 186 (discussing the "communicatively fluid sovereignty of citizens [that] instantiates itself in the power of public discourses that spring from autonomous public spheres").

47 Julian Sanchez, Killing the Internet to Save Hollywood, N.Y. PoST (Dec. 22, 2011, 11:18 AM), http://www.nypost.com/p/news/opinion/opedcolumnists/killing_the_internet_to_save_hollywood _lSWv0ymGvqWbvn5siAQgsK.

48 Open Letter from Internet Engineers to the U.S. Congress (Dec. 15, 2011), available at https://www.eff.org/sites/default/files/Internet-Engineers-Letter.pdf. 
porous enough, procedurally democratic enough, for them to be heard. The nerds were not invited to the committee hearing, but they ended up testifying anyway by means of the input channel that was open to them - the Internet, across which flow the "informal streams of communication" that Habermas identifies as critical to discursive plurality in both public opinion- and political will-formation. ${ }^{49}$

It is impossible to say, ultimately, whether the uninvited "nerd" testimony was a decisive factor in the defeat of SOPA/PIPA. It is certain, however, that the multi-vocal chorus of input from the Internet-both on behalf of the Internet and by means of the Internetturned the policymaking tide. ${ }^{50}$ If the ACTA process is an object lesson in closed policymaking, the SOPA/PIPA process is - or at least it spontaneously became - an object lesson in open policymaking, where individuals and groups from a wide range of positions and locations within the public sphere spoke out, and policymakers listened. If the public has a right to know in a democratic system, it must have a corollary right to be heard. The latter is as important as the former to the democratic legitimacy of any policymaking process.

Professor Levine's article recognizes the importance of both rights, but its ultimate focus on FOIA reform cannot help but re-inscribe an emphasis on the output side of the communicative balance. FOIA is, after all, an "information out" mechanism. And while getting more "information out" is a necessary condition for more democratically legitimate and technically sound policymaking, it is not a sufficient one. Whether in the domain of international or domestic copyright policymaking, there must be both informal and formal mechanisms for allowing members of the public, particularly those with technical expertise, to "talk back" to government. This is especially true when the object of regulation is a complex engineering infrastructure like the Internet. In the Internet age, copyright policy is technology policy, ${ }^{51}$ and making good technology policy requires advice from technologists. Informal channels of communication to government are necessary, as Habermas argues, but formal channels must also be open and accessible, as they are, for example, in the notice and public comment procedure for administrative rulemakings. How else can the Internet be saved, as it periodically must be, from the misguided policy choices of "oldfashioned guys" who neither get nor sweat "the technological stuff"?

49 HABERMAS, supra note 1 , at 171.

50 See, e.g., Grant Gross, U.S. Lawmakers Flip Their Positions on SOPA, PIPA, PCWORLD (Jan. 18, 2012, $2: 00 \quad$ PM), https://www.pcworld.com/businesscenter/article/248350/us_lawmakers_flip_their_positions_on_ sopa_pipa.html.

51 Cf. Tim Wu, Copyright's Communications Policy, 103 MiCH. L. REV. 278 (2004). 